\title{
3D Cell Technology in Biomedical Research
}

\author{
Katarina Mišković Š̉poljarić, Marijana Jukić, Teuta Opačak-Bernardi, Ljubica Glavaš-Obrovac \\ School of Medicine, Josip Juraj Strossmayer University, Osijek, Croatia
}

\begin{abstract}
A B S T R A C T
Traditional two dimensional cell culture has enabled great strides in biomedicine but needs to be improved to be able to keep up with the demands of modern biomedical research. 2D monolayer culture cannot replicate tissue responses and needs to be supplemented with extensive animal research. Growing cells in three dimensional scaffolds provides a more functional model for biomedical research than traditional monolayer culture. Depending on the needs and the complexity of the model there are several ways that $3 D$ models can be initiated. Simple spheroids can be grown in low adherence plates and in hanging drops while larger spheroids and co-cultured ones need to be grown in systems with greater support such as hydro gels. The system that offers the greatest flexibility is the magnetic levitation approach. In the paper we offer a brief resume to various $3 D$ methods and their characteristics to ease the choice of methods for implementing $3 D$ cell culture techniques.
\end{abstract}

Key words: biomedical research, cell culture, cell culture techniques, co-culture techniques, cell proliferation, animals, gels, magnetic phenomena

\section{Introduction}

Cell culture has been traditionally used in biomedical research as a well-established tool to avoid large-scale and cost- intensive tests on animals. Growing cells on flat and rigid substrate as a two dimensional (2D) monolayer is the most commonly used model in basic applicative research. Although 2D cell cultures are a good model for cell based methods, the limitations are evident when it comes to cellular response to drug treatment or other external stimu$\mathrm{li}^{1}$. In the body, cells are naturally enclosed by extracellular matrix (ECM) or in direct contact through tight junctions with other cells of the same or different lineages. Until recently, most of biological studies conducted on cell model were carried out mostly on cell monolayers in 2D form. This model is well-established, controlled, with uniform cell environment and can be monitored by microscopic evaluation. Today, 2D model is replaced with three dimensional (3D) form of cell culture because of $2 \mathrm{D}$ inconsistencies with real time conditions.

$3 \mathrm{D}$ cell culture is a new approach in scientific research platforms based on cell culture in vitro. In $3 \mathrm{D}$, cells are grown as aggregates ${ }^{2}$, on a scaffold ${ }^{3,4}$, or embedded in gel $^{5}$. $3 \mathrm{D}$ cultured cells behave essentially different then $2 \mathrm{D}$ monolayers preserving or regaining major physiological properties possessed by the original cells in vivo ${ }^{6}$. Good example are multipotent mesenchymal stromal cell (MSC)derived hepatocytes grown in 3D model. They maintain functions such as albumin and urea synthesis, as well as better ammonia and drug clearance ${ }^{4}$. Loss of function in hepatocytes and primary articular chondrocytes grown in $2 \mathrm{D}$ can be prevented or restored by $3 \mathrm{D}$ culturing 7,8 .

The most frequent usage of $3 \mathrm{D}$ is formation of aggregates named from mammosphere ${ }^{9}$, micromass ${ }^{10}$, spheroids ${ }^{11}$, to micro fabricated tissues ${ }^{12}$ with emphasis on spheroids which we will consider in this work.

\section{D Models and Applications}

In $3 \mathrm{D}$ culture, cells are formed in multilayer spheroids with cells in different stage of growth. Depending of research requirements, 3D cell culture can be formed from one cell type forming monoculture or co-culture that consists of different cell types. Viable dividing cells, are located in the outer layer of the spheroid and are exposed to cellular medium. As shown in Figure 1, center of the

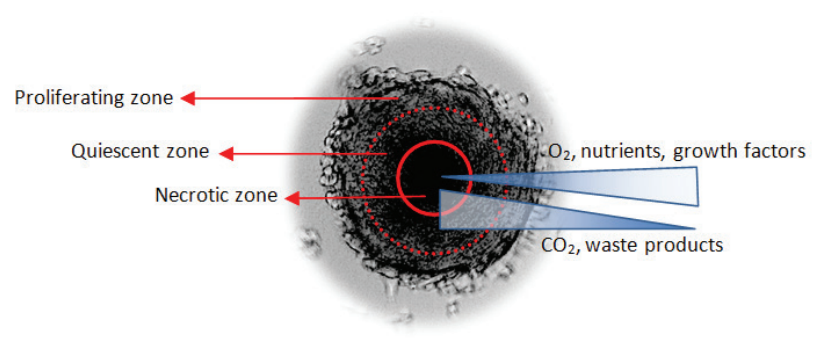

Fig. 1. Formation of $3 D$ cell spheroid and distribution of nutrients and metabolic products within the spheroids. 
2D

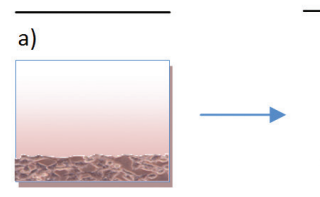

Scaffold free 3D cell culture

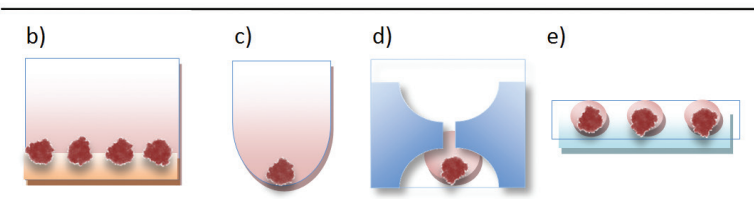

Fig. 2. Scaffold free 3D cell culture formation: a) cell monolayer, b) spheroid formation on a coated surface, c) spheroid formation in low attachment U-bottom well, d) hanging drop method on a specially designed plate, e) hanging drop method on a Petri dish lid.

spheroid is a hypoxic zone with cells in necrosis or apoptosis. Derda et al. ${ }^{13}$ indicated in cell-model called "cell-ingel-in-paper" (CiGiP) that proliferating cells are localized in the outer paper layer while necrotic and cell cycle arrested cells are in the inner paper layer ${ }^{14}$ which correlates with tumor biopsy ${ }^{13}$. Similar to native tumor tissue, cells grown as 3D culture exhibit a strong proliferation gradient that reflects the distribution of oxygen, nutrients and energy from the outer to the inner side of the spheroid. Biological characterization of 3D spheroids strongly depends on cell types and culturing conditions $s^{1,15-18}$.

Establishing a 3D cell culture can be done with or without a scaffold base with cells that have a natural tendency to aggregate and form spheroids. Scaffold free 3D cell culture methods involve aggregation of the cells in non-adherent conditions. These models of 3D cell culture are achieved by using low adhesion plates with U- or V- bottom or by coating surface with poly hydroxyethyl methacrylate or agarose (Figures $2 \mathrm{a}$ and b). Additionally, scaffold free spheroids can be grown by hanging drop method, where the drop of media containing the cells promotes cell-to-cell interaction. Hanging drop method can be done using specially designed plates or Petri dishes (Figure $2 \mathrm{c}$ and d ${ }^{16}$. Furthermore, the spheroids can be formed in a bioreactor under dynamic culturing conditions with constant fluidic flow. By using spinner flasks or microgravity bioreactors it's possible to produce a large-scale spheroid (Figure 3).

Scaffold based modeling 3D cell culture uses constructs made of biological or artificial porous materials that serve as a support in the formation of 3D spheroid structures. Artificial scaffolds are made from a variety of materials with different porosities, permeability, surface chemistries and mechanical characteristics designed to mimic the microenvironment of specific tissues. Biological scaffolds mostly use Matrigel and collagen as structural support providing physiologically relevant microenvironment of growth factors, hormones and other molecules and simulating in vivo environment ${ }^{19}$. The porous matrix contributes to optimal permeability and nutrient diffusion, mediates radial gradients and protects cells from environmental perturbation facilitating adhesion and cell migration ${ }^{20}$.

One of the newest approaches to 3D cell culture formation is magnetic levitation. Cells are not normally magnetic and to be able to levitate they need to be fed with metal nanoparticles. After that by applying magnetic force cells are levitated on the interface between media and air. Method is suitable for all cell types. All components are biocompatible and do not interfere with testing external treatments such as drugs ${ }^{21}$. During levitation cells produce their own ECM and there is no specific media that has to be used. This approach is readily scalable and does not require adaptation of existing $2 \mathrm{D}$ protocol $\mathrm{s}^{22}$. The seamless transition from $2 \mathrm{D}$ to magnetic levitation $3 \mathrm{D}$ culture makes it a good way to introduce cost effective 3D culture in your research.

Implementation of $3 \mathrm{D}$ cell culture is recognized as a good model for investigation of tissue and cell biology, tumour biology, drug discovery and toxicity, as well as for tissue engineering ${ }^{15,23}$. Mostly, 3D cell culture systems provoke rising interest in area of pharmacology and in vitro drug screening due to study of cell-cell interactions, hypoxia, drug penetration, response and resistance or production/deposition of extracellular matrix ${ }^{24}$. Growing cells in a monolayer was the most commonly used model for detection and early characterization of new small molecules that represent good candidates for further development of antitumor drugs. Although a good model for the formation of a potential molecular database, this model does not reflect the pathophysiology of solid tumours. Cells cultured in 2D exhibit modified gene expression and activation of signalling pathways. They reproduce neither tight junctions and

a)

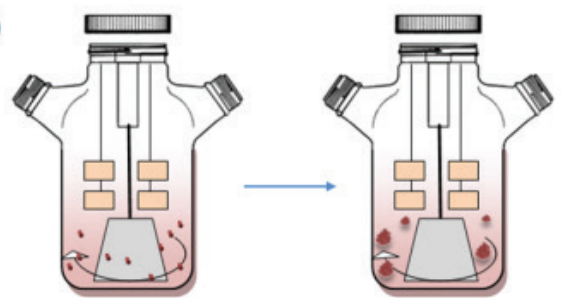

b)
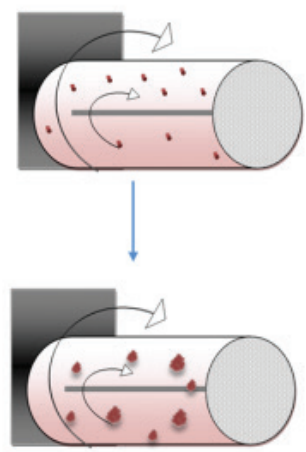

Fig. 3. Spheroid formation in a bioreactor: a) spinner flask and b) rotating vessel. 

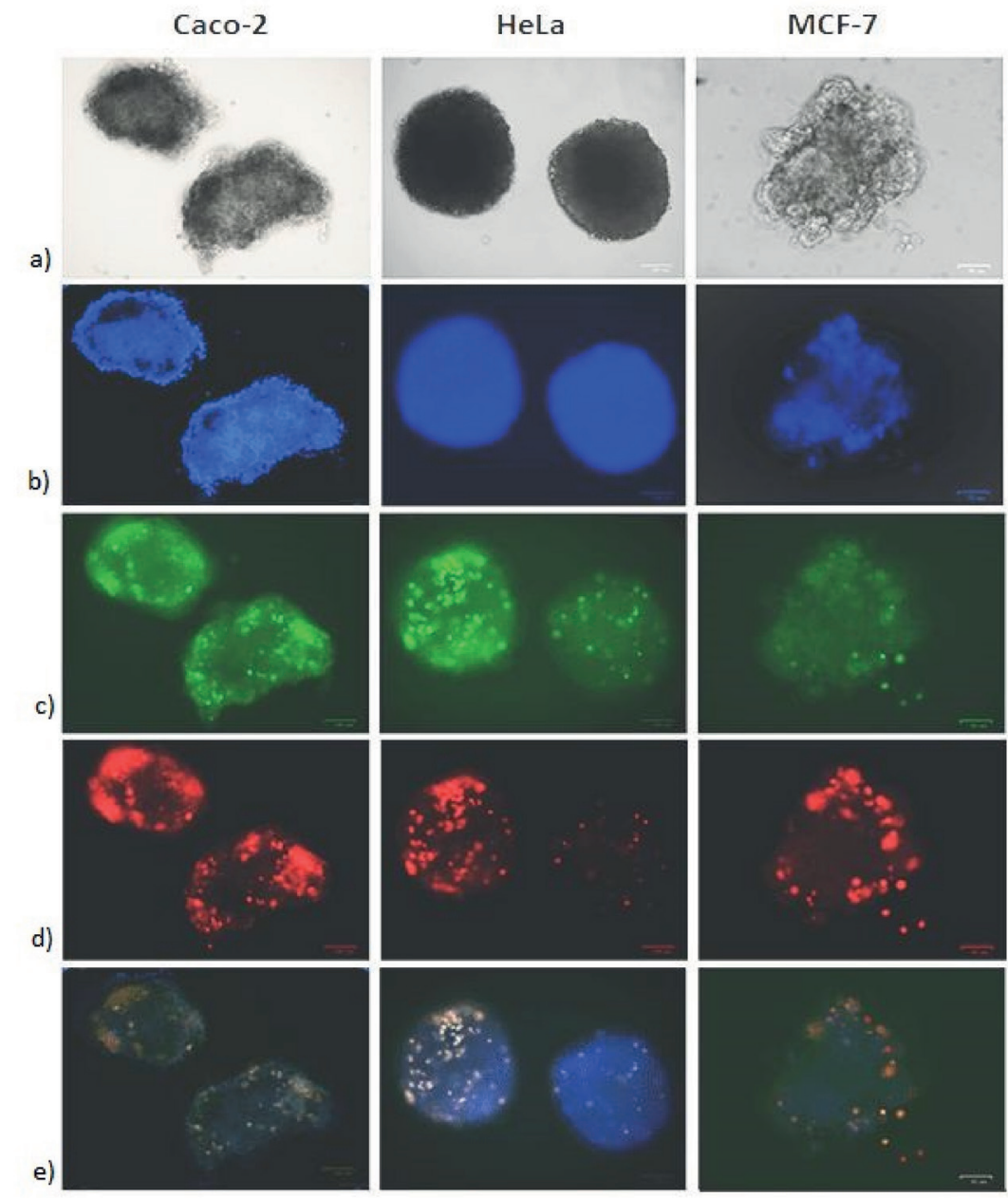

Fig. 4. Hanging drop 3D cell model. Three tumour cell lines (Caco-2, HeLa, MCF-7) are grown in culture cell media for 96 hours before exposure to different dyes as follows: a) bright field; b) Hoechst 33258; c) fluorescein isothiocyanate - FITC; d) propidium iodide - PI; e) overlay of b), c) and d). Photos are taken by ZOE TM Fluorescent Cell Imager (BIO RAD, USA) at blue LED channel (ex.355 nm / em $433 \mathrm{~nm}$ ), green LED channel (ex.480 nm / em $517 \mathrm{~nm}$ ), and red LED channel (ex.556 nm / em $615 \mathrm{~nm})$ with measurement scale $(100 \mu \mathrm{m})$.

cell-to-cell interactions nor a gradient of $\mathrm{pH}$, oxygen and nutrients, which are pivotal in tumour progression, chemo resistance and metastasis ${ }^{25}$. Native solid tumours often show hypoxia/necrosis, sporadic proliferation and uneven diffusion of drugs, which contributes to the different response to treatment ${ }^{26,27}$. Accordingly, the study of drug discovery in 3D models allows better insight into tissue specific architecture, along with elements in the enclosing microenvironment, leading to better understanding of tumour pathobiology $y^{16}$. This approach generates specific type of spheroids usually known as multicellular tumour spheroids (MCTS) which are anchorage-independent scaffoldfree spherical self-assembled aggregates ${ }^{25}$, like spheroids in Figure 4. Formed spheroids may display tumour-specific characteristics like heterogeneous proliferation, oxygen and nutrient slope, necrotic centre as well as cell-to-cell and ECM-cell contact ${ }^{28-30}$. Other type of 3D spheroid cell model is anchorage-dependent multi-layered cell culture (MCCs) grown on a membrane or specific substrate for the purpose of drug diffusion evaluation ${ }^{16}$. Each of the mentioned mod- els has a big importance in production of high -throughput, high replication, low-cost, point-of-care device for antitumor drug testing in personalized medicine ${ }^{20}$.

\section{Conclusion}

Overall, 3D culture is rapidly becoming the mainstay in laboratory practice. It is extremely valuable in differentiation studies and cell physiology research. In drug development surroundings it bridges the gap between conventional $2 \mathrm{D}$ in vitro and animal models ${ }^{24}$ ultimately arising in improved translation and downsizing the number of animals in drug discovery programs ${ }^{16}$ and preclinical research.

\section{Acknowledgment}

We thank Labena d.o.o. for providing a ZOETM Fluorescent Cell Imager (BIO RAD, USA) for testing. 


\section{R E F E R E N C E S}

1. EDMONDSON R, BROGLIE JJ, ADCOCK AF, YANG L, Assay Drug Dev Technol,12 (2014) 207. doi: 10.1089/adt.2014.573. - 2. LIN RZ, CHANG HY, Biotechnol J, 3 (2008) 1172. doi: 10.1002/biot.200700228. - 3. MORONI L, DE WIJN JR, VAN BLITTERSWIJK CA, J Biomater Sci Polym Ed, 19 (2008) 543. doi: 10.1163/156856208784089571. — 4. LI J, TAO R, WU W, CAO H, XIN J, LI J, GUO J, JIANG L, GAO C, DEMETRIOU AA, FARKAS DL, LI L, Stem Cells Dev, 19 (2010) 1427. doi: 10.1089/scd.2009.0415. - 5. SLAUGHTER BV, KHURSHID SS, FISHER OZ, KHADEMHOSSEINI A, PEPPAS NA. Adv Mater Deerfield Beach Fla, 21 (2009) 3307. doi: 10.1002/adma.200802106. - 6. LV D, HU Z, LU L, LU H, XU X, Oncol Lett, 14 (2017) 6999. doi: 10.3892/ ol.2017.7134. - 7. BIERWOLF J, LUTGEHETMANN M, FENG K, ERBES J, DEICHMANN S, TORONYI E, STIEGLITZ C, NASHAN B, MA PX, POLLOK JM, Biotechnol Bioeng, 108 (2011) 141. doi: 10.1002/ bit.22924. - 8. MARK KVD, GAUSS V, MARK HVD, MÜLLER P, Nature, 267 (1977) 531. doi: 10.1038/267531a0. - 9. KLOPP AH, LACERDA L, GUPTA A, DEBEB BG, SOLLEY T, LI L, SPAETH E, XU W, ZHANG X, LEWIS MT, REUBEN JM, KRISHNAMURTHY S, FERRARI M, GASPAR R, BUCHHOLZ TA, CRISTOFANILLI M, MARINI F, ANDREEFF M, WOODWARD WA, PloS One, 5 (2010) e12180. doi: 10.1371/ journal.pone.0012180. - 10. GRECO KV, IQBAL AJ, RATTAZZI L, NALESSO G, MORADI-BIDHENDI N, MOORE AR, GOLDRING MB, DELL'ACCIO F, PERRETTI M. Biochem Pharmacol, 82 (2011) 1919. doi: 10.1016/j.bcp.2011.09.009. - 11. RIVRON NR, RAISS CC, LIU J, NANDAKUMAR A, STICHT C, GRETZ N, TRUCKENMÜLLER R, ROUWKEMA J, VAN BLITTERSWIJK CA, Proc Natl Acad Sci USA, 109 (2012) 4413. doi: 10.1016/j.bcp.2011.09.009. - 12. RIVRON NC, ROUWKEMA J, TRUCKENMÜLLER R, KARPERIEN M, DE BOER J, VAN BLITTERSWIJK CA, Biomaterials, 30 (2009) 4851. doi: 10.1016/j.biomaterials.2009.06.037. - 13. DERDA R, TANG SKY, LAROMAINE A, MOSADEGH B, HONG E, MWANGI M, MAMMOTO A, INGBER DE, WHITESIDES GM, PloS One, 6 (2011) e18940. doi: 10.1371/journal. pone.0018940. - 14. MONTANEZ-SAURI SI, BEEBE DJ, SUNG KE, Cell Mol Life Sci CMLS, 72 (2015) 237. doi: 10.1007/s00018-014-1738-5.
- 15. HIRSCHHAEUSER F, MENNE H, DITTFELD C, WEST J, MUELLER-KLIESER W, KUNZ-SCHUGHART LA, J Biotechnol, 148 (2010) 3. doi: 10.1016/j.jbiotec.2010.01.012. - 16. LOVITT CJ, SHELPER TB, AVERY VM, Biology (Basel), 3 (2014) 345. doi: 10.3390/biology3020345. - 17. WENZEL C, RIEFKE B, GRÜNDEMANN S, KREBS A, CHRISTIAN S, PRINZ F, OSTERLAND M, GOLFIER S, RÄSE S, ANSARI N, ESNER M, BICKLE M, PAMPALONI F, MATTHEYER C, STELZER EH, PARCZYK K, PRECHTL S, STEIGEMANN P, Exp Cell Res, 323 (2014) 131. doi: 10.1016/j.yexcr.2014.01.017. — 18. BRAJŠA K, TRZUN M, ZLATAR I, JELIĆ D, Period Biol, 118 (2016) 59. DOI: 10.18054/pb.2016.118.1.3940. — 19. Fang Y, EGLEN RM, Discov, 22 (2017) 456. doi: 10.1177/1087057117696795. — 20. HAN WJ, YUAN W, ZHU JR, FAN Q, QU J, LIU LY, Chinese Physics B, 25 (2015) 18709. DOI: 10.1088/1674-1056/25/1/018709. — 21. SOUZA GR, MOLINA JR, RAPHAEL RM, OZAWA MG, STARK DJ, LEVIN CS, BRONK LF, ANANTA JS, MANDELIN J, GEORGESCU MM, BANKSON JA, GELOVANI JG, KILLIAN TC, ARAP W, PASQUALINI R, Nat Nanotechnol, 5 (2010) 291. doi: 10.1038/nnano.2010.23. - 22. HAISLER WL, TIMM DM, GAGE JA, TSENG H, KILLIAN TC, SOUZA GR, Nat Protoc, 8 (2013) 1940. doi: 10.1038/nprot.2013.125. - 23. GAO G, CUI X, Biotechnol Lett, 38 (2016) 203. doi: 10.1007/s10529-015-1975-1. — 24. ZANONI M, PICCININI F, ARIENTI C, ZAMAGNI A, SANTI S, POLICO R, BEVILACQUA A, TESEI A, Sci Rep, 6 (2016) 19103. doi: 10.1038/ srep19103. — 25. LAZZARI G, NICOLAS V, MATSUSAKI M, AKASHI M, COUVREUR P, MURA S, Acta Biomater, 78 (2018) 296. doi: 10.1016/j. actbio.2018.08.008. - 26. BRESLIN S, O'DRISCOLL L, Drug Discov Today, 18 (2013) 240. doi: 10.1016/j.drudis.2012.10.003. - 27. THOMA CR, ZIMMERMANN M, AGARKOVA I, KELM JM, KREK W, Adv Drug Deliv Rev, 69 (2014) 29. doi: 10.1016/j.addr.2014.03.001. - 28. KUNZSCHUGHART LA, Cell Biol Int, 23 (1999) 157. doi: 10.1006/ cbir.1999.0384. - 29. FRIEDRICH J, EBNER R, KUNZ-SCHUGHART LA, Int J Radiat Biol, 83 (2007) 849. doi: 10.1080/09553000701727531. — 30. MUELLER-KLIESER W, Crit Rev Oncol Hematol, 36 (2000) 123. doi: 10.1016/s1040-8428(00)00082-2.

\author{
K. Mišković Špoljarić \\ School of Medicine, University of Osijek, Josipa Huttlera 4, 31000 Osijek, Croatia \\ e-mail:kmiskovic@mefos.hr
}

3D STANIČNA TEHNOLOGIJA U BIOMEDICINSKIM ISTRAŽIVANJIMA

\title{
S A Ž E T A K
}

Klasična dvodimenzionalna stanična kultura omogućila je veliki napredak u biomedicini, ali potrebno ju je unaprijediti kako bi odgovorila zahtjevima modernih biomedicinskih istraživanja. Monoslojna 2D kultura ne može replicirati tkivni odgovor i potrebno ju je nadopuniti iscrpnim istraživanjima na životinjama. Uzgoj stanica u trodimenzionalnim potpornim sustavima rezultira funkcionalnijim biomedicinskim modelima u odnosu na klasične monoslojne kulture. U ovisnosti o potrebama i složenosti istraživanja, 3D modeli se mogu formirati na nekoliko načina. Jednostavni sferoidi se mogu uzgojiti kao viseća kap te na slabo adherirajućim površinama dok se veliki sferoidi i ko-kulture uzgajaju u jačim sustavima podrške poput hidrogelova. Magnetska levitacija je jedan od načina pripreme koji omogućuje najveću fleksibilnost u uzgoju sferoida. U radu ćemo ponuditi kratki pregled različitih 3D modela i njihovih karakteristika kako bismo olakšali odabir metode kod uspostave 3D kulture. 